\title{
Preparation of Fluoro- and Bromofluoroaryl Compounds by Copyrolysis of Bromofluoroalkanes ${ }^{*}$
}

\author{
Leo A. Wall, James E. Fearn, Walter J. Pummer, and Robert E. Lowry
}

\author{
(February 14, 1961)
}

\begin{abstract}
Pyrolysis of tribromofluoromethane yields chiefly hexafluorobenzene. Copyrolysis of this material with several bromine-containing compounds was studied at $540{ }^{\circ} \mathrm{C}$ and under several atmospheres' pressure of nitrogen gas. The addition of bromine or dibromodifluoromethane has very little effect on the pyrolysis products of tribromofluoromethane. Copyrolysis with carbon tetrabromide or bromoform yields increased amounts of bromopentafluorobenzene and dibromotetrafluorobenzene at the expense of hexafluorobenzene. The addition of relatively small amounts of 1,1,1-tribromo-2,2,2-trifluoroethane gives a significant yield of octafluorotoluene.
\end{abstract}

\section{Introduction}

Synthesis of hexafluorobenzene by the pyrolysis of tribromofluoromethane has been described and investigated by several workers $[1-4]^{1}$. The original synthesis [1] was carried out at atmospheric pressure and $640{ }^{\circ} \mathrm{C}$. In a previous study of this reaction in our laboratory [2], we explored the effects of pressure and temperature. On increasing the pressure to $4 \mathrm{~atm}$, optimum yields were obtained near $540{ }^{\circ} \mathrm{C}$, and the maximum yields were somewhat greater than at atmospheric pressure. A secondary product from the pyrolysis of tribromofluoromethane was bromopentafluorobenzene $[2,3]$. Since this material has great value in synthesis work [5], it was of interest to find means of increasing the relative yield of this product. A conceivable approach to this aim would be to increase the concentration of bromine in the reaction or to introduce carbon tetrabromide or bromoform into the reaction. Introduction of other compounds, it was anticipated, could also lead to the synthesis of various derivatives of hexafluorobenzene or related compounds.

\section{Materials}

The tribromofluoromethane, obtained from Columbia Organic Chemicals, Inc., was dried over anhydrous calcium sulfate and filtered through glass wool. The carbon tetrabromide, bromoform, and bromine were reagent grades and were used without further purification. The 1,1,1-trifluoroethane was a research sample. ${ }^{2}$ The dibromodifluoromethane was obtained as a byproduct in the pyrolytic preparation of hexafluorobenzene.

The tribromotrifluoroethane was prepared by first converting $\mathrm{CF}_{3} \mathrm{CH}_{3}$ to $\mathrm{CF}_{3} \mathrm{CHBr}_{2}$ by thermal reaction with $\mathrm{Br}_{2}$ in a hot-tube apparatus [6]. Then, in a one-liter, three-necked flask equipped with an efficient stirrer and a reflux condenser, a mixture of

*Based on Research Supported by Bureau of Naval Weapons, U.S. Navy.

1 Figures in brackets indicate the literature references at the end of this paper. Corporation, in supplying this material is gratefully acknowledged.
$242 \mathrm{~g}$ (1 mole) of $\mathrm{CF}_{3} \mathrm{CHBr}_{2}, 135 \mathrm{~g}$ of $\mathrm{KOBr}$ (prepared from $112 \mathrm{~g}$ of $\mathrm{KOH}$ and $160 \mathrm{~g}$ of $\mathrm{Br}_{2}$ ), and $300 \mathrm{ml}$ of water was cooled for $3 \mathrm{hr}$ in a bath maintained at $15{ }^{\circ} \mathrm{C}$. The mixture was stirred vigorously and irradiated with a 350-watt bulb throughout the reaction. When the exothermic reaction had subsided and the contents of the flask had cooled, the product solidified. The aqueous layer was decanted. The slightly yellow product, 1,1,1-tribromo-2,2,2trifluoroethane, was briefly dried in air and sublimed. The yield was $257 \mathrm{~g}(80 \%)$.

\section{Experimental Procedures}

The pyrolysis experiments were carried out as described previously [2]. However, the apparatus used was newly constructed and designed to handle 2 liters of reactants or about $5 \mathrm{~kg}$ of tribromofluoromethane. A diagram of the apparatus is shown in figure 1. The pyrolysis tube, platimun 89 percent and ruthenium 11 percent, $76 \mathrm{~cm}$ long, $0.95 \mathrm{~cm}$ ID, and $1.15 \mathrm{~cm} \mathrm{OD,} \mathrm{was} \mathrm{silver-soldered} \mathrm{to} \mathrm{brass} \mathrm{fittings}$ at each end. The reservoir and traps were constructed of welded stainless steel and connected via copper tubing and brass fittings. The only nonmetal component of the apparatus was a thickwalled, hard-glass, solenoid valve which controlled the input of liquid $\mathrm{CBr}_{3} \mathrm{~F}$ mixtures into the furnace. This glass valve was connected with two glass inner $10 / 30$ standard tapers to two outer $10 / 30$ tapers machined out of brass and silver soldered to copper tubing. The taper joints were waxed together with poly(chlorotrifluoroethylene) wax.

The reservoir was filled with the reactants. Then, after closing the system and bringing the furnace to the desired temperature, set on an indicating, proportioning controller operating from a thermocouple, the pressure of $\mathrm{N}_{2}$ gas in the system was adjusted, using the reducing valve on the gas cylinder. The flow of $\mathrm{N}_{2}$, which had been prepurified, was adjusted by bleeding through a brass, bluntneedle valve at the exhaust end of the apparatus. Finally an electric timer was switched on, which periodically allowed pulses of liquid $\mathrm{CBr}_{3} \mathrm{~F}$ mix- 
tures to enter the furnace. After the reservoir was emptied the apparatus was shut down and the pressure allowed to drop to atmospheric. The products were drained from the first trap, which was operated at room temperature. Very little material was found in the second trap, which was operated at $-78{ }^{\circ} \mathrm{C}$, but its use tended to prevent corrosion of the exhaust valve. The products were worked up as described previously [1-4].

\section{Results}

Mixtures of $\mathrm{CBr}_{3} \mathrm{~F}$ with $\mathrm{CBr}_{4}$, with $\mathrm{CHBr}_{3}$, with $\mathrm{Br}_{2}$, with $\mathrm{CBr}_{2} \mathrm{~F}_{2}$, and with $\mathrm{CF}_{3} \mathrm{CBr}_{3}$ were pyrolyzed under conditions listed in table 1 . The last three columns in the table give the total amount of recovered material, the weight percent of debromination, and the total weight of products other than bromine. The conditions used were approximately the optimum ones for the production of $\mathrm{C}_{6} \mathrm{~F}_{6}$. The experiments with the first three substances listed were carried out to explore the possibility of syn- thesizing greater amounts of $\mathrm{C}_{6} \mathrm{BrF}_{5}$ and $\mathrm{C}_{6} \mathrm{Br}_{2} \mathrm{~F}_{4}$. After pyrolysis, the material was first treated to remove $\mathrm{Br}_{2}$ and then distilled. The fractions collected were analyzed, using a mass spectrometer.

Results from the copyrolysis of $\mathrm{CBr}_{3} \mathrm{~F}$ with $\mathrm{CBr}_{4}$ are given in table 2 , along with boiling points, weights, and analyses of the fractions. Quantitative results, when given, are expressed in mole percent. A few compounds are merely listed when found in trace amounts. The addition of $\mathrm{CBr}_{4}$ decreases the yield of $\mathrm{C}_{6} \mathrm{~F}_{6}$ and increases the yields of $\mathrm{C}_{6} \mathrm{BrF}_{5}$ and $\mathrm{C}_{6} \mathrm{Br}_{2} \mathrm{~F}_{4}$. However, the major material was the $\mathrm{C}_{6} \mathrm{Br}_{2} \mathrm{~F}_{4}$ and not the more desirable $\mathrm{C}_{6} \mathrm{BrF}_{5}$.

Table 3 gives the results from copyrolysis of the $\mathrm{CBr}_{3} \mathrm{~F}$ with $\mathrm{CHBr}_{3}$. Surprising amounts of $\mathrm{C}_{6} \mathrm{BrF}_{5}$ and $\mathrm{C}_{6} \mathrm{Br}_{2} \mathrm{~F}_{4}$ are produced. From $\mathrm{CHBr}_{3}$ it was initially conceivable that $\mathrm{C}_{6} \mathrm{HF}_{5}$ or even $\mathrm{C}_{6} \mathrm{H}_{2} \mathrm{~F}_{4}$ could be a product. However, no products containing hydrogen were detected, excluding the $\mathrm{HBr}$ which was qualitatively evident in the exhaust gases.

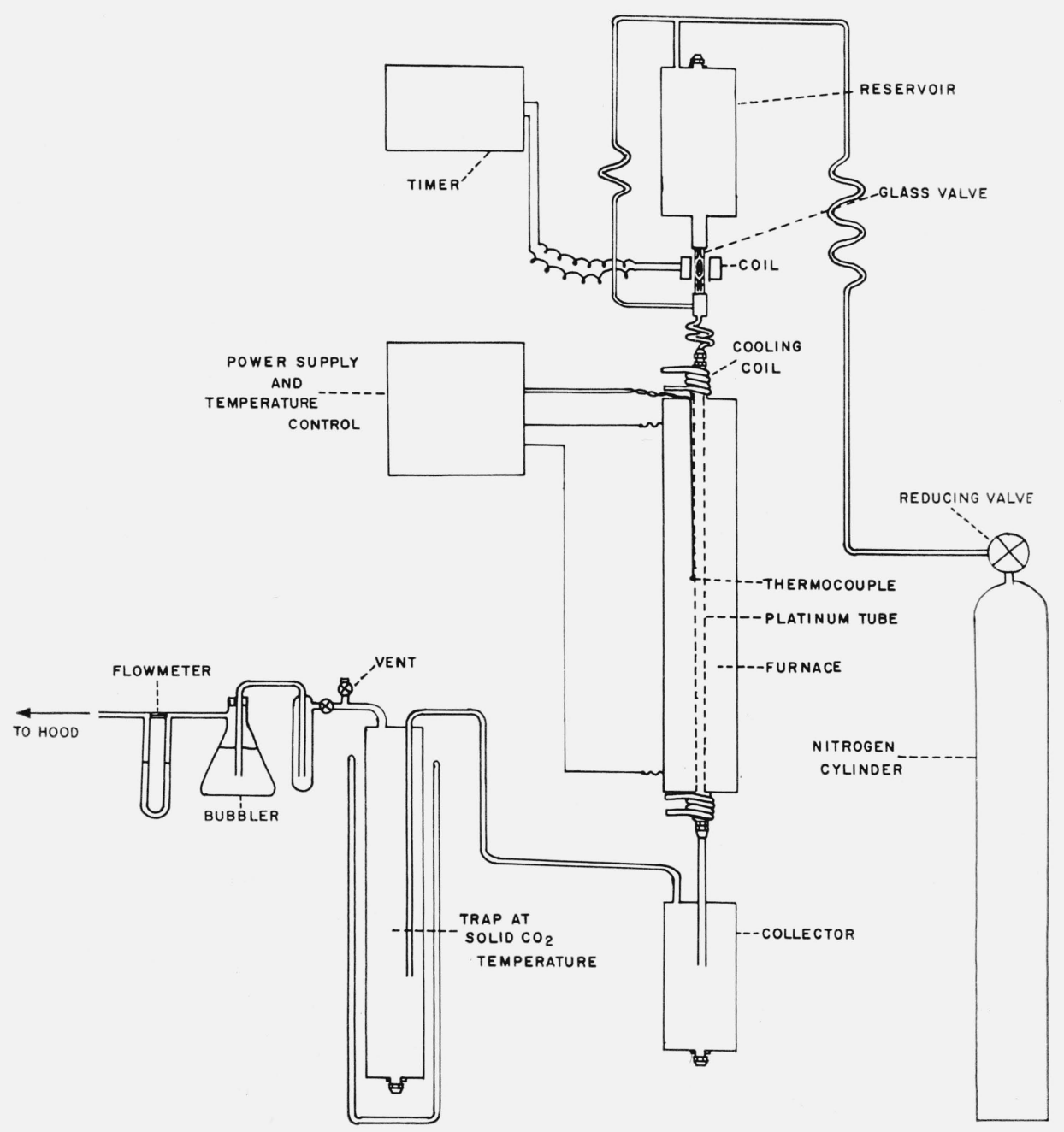

Figure 1. Apparatus for pyrolysis of bromofluorocarbon liquids under pressure. 
TABle 1. Pyrolysis of bromofluorocarbon mixtures

\begin{tabular}{|c|c|c|c|c|c|c|c|c|c|}
\hline Mixtures & Weight & Moles & $\begin{array}{l}\text { Tempera- } \\
\text { ture }\end{array}$ & Pressure & $\mathrm{N}_{2}$ flow & Time & $\begin{array}{c}\text { Recovered } \\
\text { material } \\
\text { (including } \\
\mathrm{Br}_{2} \text { ) }\end{array}$ & $\begin{array}{l}\mathrm{Br}_{2} \text { re- } \\
\text { moval }\end{array}$ & $\begin{array}{c}\text { Products } \\
\text { (other than } \\
\mathrm{Br}_{2} \text { ) }\end{array}$ \\
\hline & $g$ & & ${ }^{\circ} \mathrm{C}$ & atm & $\mathrm{cm}^{3} / \mathrm{min}$ & $h r$ & $\%$ & $\%$ & $g$ \\
\hline $\begin{array}{l}\mathrm{CBr}_{3} \mathrm{~F}_{\ldots} \ldots \ldots \\
\mathrm{CBr}_{4} \ldots \ldots\end{array}$ & $\begin{array}{r}2981 \\
756\end{array}$ & $\begin{aligned} 11 \\
2.2\end{aligned}$ & 540 & 18 & 25 & 5 & 98 & 87 & 652 \\
\hline $\begin{array}{l}\mathrm{CBr}_{3} \mathrm{~F}_{\ldots} \ldots \ldots \\
\mathrm{CBr}_{4} \ldots \ldots\end{array}$ & $\begin{array}{l}7859 \\
1307\end{array}$ & $\stackrel{29}{3.8}$ & 540 & 18 & 25 & 7 & 67 & 87 & 1721 \\
\hline $\begin{array}{l}\mathrm{CBr}_{3} \mathrm{~F}_{\ldots} \ldots \ldots \\
\mathrm{CBr}_{4} \ldots \ldots\end{array}$ & $\begin{array}{l}4490 \\
1100\end{array}$ & $\begin{array}{r}16.5 \\
3.3\end{array}$ & 545 & 3.5 & 25 & 5. 2 & 98.5 & 69.8 & 740 \\
\hline $\begin{array}{l}\mathrm{CBr}_{3} \mathrm{~F}_{\ldots} \ldots \ldots \\
\mathrm{CHBr} \\
\end{array}$ & $\begin{array}{r}4065 \\
759\end{array}$ & $\begin{array}{l}15 \\
3.1\end{array}$ & 560 & 10 & 25 & 11. 3 & 95 & 96 & 769 \\
\hline $\begin{array}{l}\mathrm{CBr}_{3} \mathrm{~F}_{\ldots} \ldots \ldots \ldots \\
\mathrm{Br}_{2 \ldots} \ldots \ldots \ldots\end{array}$ & $\begin{array}{l}3400 \\
1360\end{array}$ & $\begin{array}{r}12.5 \\
8.5\end{array}$ & 540 & 10 & 50 & 11 & 70 & $49^{\mathrm{a}}$ & \begin{tabular}{l}
\multicolumn{1}{c}{416} \\
$9 \mathrm{C}_{6} \mathrm{~F}_{6}$ \\
$197 \mathrm{CBr}_{3} \mathrm{~F}$ \\
210Residue
\end{tabular} \\
\hline $\begin{array}{l}\mathrm{CBr}_{3} \mathrm{~F}_{\ldots} \ldots \ldots \ldots \\
\mathrm{CBr}_{2} \mathrm{~F}_{2 \ldots \ldots} \ldots \ldots\end{array}$ & $\begin{array}{r}2710 \\
420\end{array}$ & $\begin{array}{r}10 \\
2\end{array}$ & 540 & 10 & 25 & 5 & 77 & 68 & $\begin{array}{l}\quad 420 \\
84 \mathrm{C}_{6} \mathrm{~F}_{6} \\
210 \mathrm{CBr}_{3} \mathrm{~F} \\
\text { 126Residue }\end{array}$ \\
\hline $\begin{array}{l}\mathrm{CBr}_{3} \mathrm{~F}_{\mathrm{CF}_{3} \mathrm{CBr}_{3} \ldots \ldots} \ldots\end{array}$ & $\begin{array}{r}1900 \\
210\end{array}$ & $\begin{array}{c}\text { 10. } 7 \\
1\end{array}$ & 560 & 10 & 25 & 4 & 98 & 74 & 793 \\
\hline
\end{tabular}

a Does not include the added bromine.

TABLE 2. Fractional distillation of products from the pyrolysis of $\mathrm{CBr}_{3} \mathrm{~F} / \mathrm{CBr}_{4}$ mixtures

\begin{tabular}{|c|c|c|c|}
\hline Boiling range & Pressure & $\begin{array}{l}\text { Weight of } \\
\text { fraction }\end{array}$ & Analysis of fraction \\
\hline${ }^{\circ} \mathrm{C}$ & $\mathrm{mm}$ & $\mathrm{g}$ & Mole $\%$ \\
\hline $\begin{array}{l}25 \text { to } 90 \\
90 \text { to } 120- \\
120 \text { to } 145 \\
85 \text { to } 95 \\
88 \text { to } 98 \\
>100\end{array}$ & $\begin{array}{l}\text { at } 760 \\
\text { at } 760 \\
\text { at } 760 \\
\text { at } 25 \\
\text { at } 10 \\
\text { at } 10\end{array}$ & $\begin{array}{l}139 \\
848 \\
160 \\
218 \\
61.5 \\
268\end{array}$ & $\begin{array}{l}\mathrm{C}_{6} \mathrm{~F}_{6}(80 \%), \mathrm{CBrFCBrF}_{6}(10 \%), \mathrm{CBr}_{2} \mathrm{~F}_{2} \\
\mathrm{CBr}_{3} \mathrm{~F}(90 \%), \mathrm{C}_{3} \mathrm{Br}_{4} \mathrm{~F}_{2}, \mathrm{C}_{6} \mathrm{BrF}_{5} \\
\mathrm{C}_{6} \mathrm{BrF}_{5}(79 \%), \mathrm{C}_{2} \mathrm{Br}_{4} \mathrm{~F}_{2}(20 \%), \mathrm{C}_{7} \mathrm{BrF}_{7} \\
\mathrm{C}_{6} \mathrm{Br}_{2} \mathrm{~F}_{4}(90 \%), \mathrm{C}_{2} \mathrm{Br}_{4} \mathrm{~F}_{2}, \mathrm{C}_{6} \mathrm{BrF}_{5} \\
\mathrm{C}_{6} \mathrm{Br}_{2} \mathrm{~F}_{4}(50 \%), \mathrm{C}_{2} \mathrm{Br}_{4}(10 \%) \\
\text { Not analyzed. }\end{array}$ \\
\hline
\end{tabular}

$\mathrm{Br}_{2}$ seemed to lower the extent of reaction; $\mathrm{CBr}_{2} \mathrm{~F}_{2}$ appeared to have no significant effect. These materials are products from the pyrolysis of $\mathrm{CBr}_{3} \mathrm{~F}$ itself

Copyrolysis with $\mathrm{CF}_{3} \mathrm{CBr}_{3}$ gave a significant yield of $\mathrm{C}_{6} \mathrm{~F}_{5} \mathrm{CF}_{3}$, as anticipated (see table 4). This material was also found in the pyrolysis products along with $\mathrm{C}_{6} \mathrm{~F}_{6}$ [3] at $800{ }^{\circ} \mathrm{C}$. However, under the conditions used here it is evident that it is produced as a result of the copyrolysis. This material is difficult to separate from the mixture in which it is produced.

TABLE 3. Fractional distillation of products from the pyrolysis of $\mathrm{CBr}_{3} \mathrm{~F} / \mathrm{CHBr}_{3}$ mixtures

\begin{tabular}{|c|c|c|}
\hline $\begin{array}{l}\text { Boiling range } \\
\text { at } 760 \mathrm{~mm}\end{array}$ & $\begin{array}{l}\text { Weight } \\
\text { of } \\
\text { fraction }\end{array}$ & Analysis of fraction \\
\hline${ }^{\circ} \mathrm{C}$ & $g$ & Mole $\%$ \\
\hline $\begin{array}{l}45 \text { to } 100 \\
100 \text { to } 125 \\
125 \text { to } 140 \\
140 \text { to } 175 \\
175 \text { to } 200\end{array}$ & $\begin{array}{r}69.4 \\
510.4 \\
69.1 \\
39.7 \\
94.8\end{array}$ & $\begin{array}{l}\mathrm{C}_{6} \mathrm{~F}_{6}(70 \%), \mathrm{CHFBr}_{2}(20 \%) \\
\mathrm{CBr}_{3} \mathrm{~F}(90 \%), \mathrm{C}_{2} \mathrm{Br}_{3} \mathrm{~F} \\
\mathrm{C}_{6} \mathrm{BrF}_{5}(60 \%), \mathrm{CHBr}_{3}(30 \%), \mathrm{C}_{7} \mathrm{BrF}_{7}, \mathrm{C}_{6} \mathrm{HBrF}_{4} \\
\mathrm{C}_{4} \mathrm{Br}_{3} \mathrm{~F}_{3}, \mathrm{C}_{3} \mathrm{Br}_{3} \mathrm{~F}_{3}, \mathrm{C}_{8} \mathrm{BrF}_{7} \\
\mathrm{C}_{6} \mathrm{Br}_{2} \mathrm{~F}_{4}, \mathrm{C}_{2} \mathrm{Br}_{4} \mathrm{~F}_{2}\end{array}$ \\
\hline
\end{tabular}

Unfortunately, our supply of $\mathrm{CF}_{3} \mathrm{CBr}_{3}$ was quite limited, and experiments with greater ratios of this material to $\mathrm{CFBr}_{3}$ were not carried out. It is evident, however, that greater ratios would produce such substances as perfluoroxylenes.

TABLE 4. Fractional distillation of products from the pyrolysis of $\mathrm{CBr}_{3} \mathrm{~F} / \mathrm{CF}_{3} \mathrm{CBr}_{3}$ mixtures

\begin{tabular}{|c|c|c|}
\hline $\begin{array}{l}\text { Boiling range } \\
\text { at } 760 \mathrm{~mm}\end{array}$ & $\begin{array}{l}\text { Weight } \\
\text { of } \\
\text { fraction }\end{array}$ & Analysis of fraction \\
\hline${ }^{\circ} \mathrm{C}$ & $g$ & Mole $\%$ \\
\hline $\begin{array}{l}50 \text { to } 95 \\
95 \text { to } 106 \\
106 \text { to } 110 \\
>110\end{array}$ & $\begin{array}{r}51.2 \\
51.7 \\
302.9 \\
401\end{array}$ & $\begin{array}{l}\mathrm{C}_{6} \mathrm{~F}_{6}(66 \%), \mathrm{C}_{6} \mathrm{~F}_{5} \mathrm{CF}_{3}(5 \%), \mathrm{C}_{6} \mathrm{~F}_{4} \mathrm{Br}_{2} \\
\mathrm{CBr}_{3} \mathrm{~F}(85 \%), \mathrm{C}_{7} \mathrm{~F}_{8}(10 \%), \mathrm{C}_{6} \mathrm{~F}_{6}(5 \%) \\
\mathrm{CBr}_{3} \mathrm{~F}(90 \%), \mathrm{C}_{7} \mathrm{~F}_{8}(5 \%), \mathrm{C}_{2} \mathrm{Br}_{3} \mathrm{~F}_{3} \\
\text { Not analyzed. }\end{array}$ \\
\hline
\end{tabular}

\section{Discussion}

The results obtained here are compatible with the type of mechanism assumed previously for this pyrolysis. The stages of reaction can be visualized thus:

$$
\begin{aligned}
& 2 \mathrm{CBr}_{3} \mathrm{~F} \longrightarrow \mathrm{CBr}_{2} \mathrm{FCBr}_{2} \mathrm{~F}+\mathrm{Br}_{2} \\
& \mathrm{CBr}_{2} \mathrm{FCBr}_{2} \mathrm{~F} \longrightarrow \mathrm{CBrF}=\mathrm{CBrF}+\mathrm{Br}_{2} \\
& 3 \mathrm{CBrF}=\mathrm{CBrF} \longrightarrow \mathrm{C}_{6} \mathrm{Br}_{6} \mathrm{~F}_{6} \text { or } \mathrm{C}_{6} \mathrm{Br}_{4} \mathrm{~F}_{6}+\mathrm{Br}_{2} \\
& \mathrm{C}_{6} \stackrel{\mathrm{F}}{6}_{6}^{\stackrel{\mathrm{C}_{6}}{\stackrel{\downarrow}{\mathrm{F}_{6}}}-3 \mathrm{Br}_{2} \downarrow}-2 \mathrm{Br}_{2}
\end{aligned}
$$


No perhalocyclohexanes have been isolated. The effect of pressure in enhancing the yield can be explained on this type of mechanism [2] without $\mathrm{CF} \equiv \mathrm{CF}$ as an intermediate. The intermediate, $\mathrm{CBrF}=\mathrm{CBrF}$, was found in the products in trace amounts, but no evidence was found for $\mathrm{CF} \equiv \mathrm{CF}$ as an intermediate. The $\mathrm{C}_{6} \mathrm{Br}_{6} \mathrm{~F}_{6}$ or the $\mathrm{C}_{6} \mathrm{Br}_{4} \mathrm{~F}_{6}$ shown are presumed to be extremely unstable; a FischerHirshfelder model of these compounds indicates large steric effects. No evidence exists for the formation of such compounds from $\mathrm{C}_{6} \mathrm{~F}_{6}$ and $\mathrm{Br}_{2}$, although the $\mathrm{C}_{6} \mathrm{Cl}_{6} \mathrm{~F}_{6}$ has been made [1]. The chlorine derivative thermally decomposes near 250 to $300{ }^{\circ} \mathrm{C}$.

It has been reported that $\mathrm{CF} \equiv \mathrm{CF}$ forms a dimer, presumably tetrafluorocyclobutadiene [7]. So far, no evidence exists for these compounds from the pyrolysis reaction of $\mathrm{CBr}_{3} \mathrm{~F}$. However, $\mathrm{CF} \equiv \mathrm{CH}$ does trimerize to 1,2,4-trifluorobenzene [8], and hexafluoro-2-butyne trimerizes to hexa(trifluoromethyl)benzene [9].

\section{References}

[1] Y Desirant, Bull. Acad. Roy. Belg., Classe Sci., [5] 41, 759 (1955).

[2] M. Hellmann, E. Peters, W. J. Pummer, and L. A. Wall, J. Am. Chem. Soc., 79, 5654 (1957).

[3] Y. Desirant, Bull. Soc. Chim. Belg. 6\%, 676 (1958).

[4] J. M. Birchall and R. N. Hazeldine, J. Chem. Soc. 13, (1959).

[5] W. J. Pummer and L. A. Wall, J. Research NBS 63A, 167 (1959).

[6] E. T. MicBee, H. B. Hass, W. G. Toland, Jr., and A. Truchan, Ind. Eng. Chem. 39, 420 (1947).

[7] W. J. Middleton, U.S. Patent No. 2,831,835, April 22, 1958.

[8] W. J. Middleton and W. H. Sharkey, J. Am. Chem. Soc. 81, 803 (1959).

[9] H. C. Brown, H. L. Gewanter, D. M. White, and W. G. Woods, J. Org. Chem. 25, 634 (1960).

(Paper 65A3-107) 